Marquette University

e-Publications@Marquette

Economics Faculty Research and Publications

Economics, Department of

$1-1-2014$

\title{
Mark Blaug on the Historiography of Economics
}

John B. Davis

Marquette University, john.davis@marquette.edu

Published version. "Mark Blaug on the Historiography of Economics," in Mark Blaug: Rebel with Many Causes. Eds. Marcel Boumans and Matthias Klaes. Cheltenham: Edward Elgar Publishing, 2013: 159-176. Publisher Link. (C) 2013 Edward Elgar Publishing. Used with permission. 


\title{
12. Mark Blaug on the historiography of economics
}

\author{
John B. Davis*
}

In the face of ideas, many economists are simply philistines, like troglodytes listening to a Beethoven quartet and asking why the four players seem to be unable to bow in unison. (Blaug 1994, p. 18)

\subsection{INTRODUCTION: THE CONTEXT AND BLAUG'S RESPONSE}

Mark Blaug was a highly accomplished and influential historian of economic thought and economic methodologist who re-thought his views about the historiography of economics late in his career in connection with his increased concern over the declining place of the history of economic thought in the economics profession in the 1990s (Blaug 2001). Indeed he was provoked to reflect again upon the historiography of economics by the stated and implicit views on the subject held by many non-historian economists, which had emerged as their grounds for justifying the expulsion and near exclusion of the history of economics from the doctoral curriculum in most American universities by the end of the decade. Though many non-historians supported or acquiesced in this development for reasons often unrelated to their views about the history of economics, such as their desire to increase the time students devoted to training in mathematics and econometrics, their willingness to sacrifice the history of economic thought effectively led them into arguing that the field had no significant value for economics as a science. This entailed a particular view of the historiography of economics, specifically, a combination of two related propositions: (1) the Whig idea that science always makes progress which renders past 'knowledge' irrelevant to current knowledge, and (2) the view that progress in economics as a science consists in analytical achievements which are by nature strongly separable from their origins and manner of development. Thus to combat 
the profession's stance toward the history of economics, Blaug needed to be able to explain why this particular historiographic view of economics was mistaken. But this proved an especially difficult task for him personally, because he had held historiographic views earlier in his career that were not far removed from the positions he had since found he wanted to reject. This chapter seeks to explain how he pulled off the move from his earlier to his later view, and thereby set out his final understanding of the historiography of economics as the methodology of the history of economics.

The chapter argues that the key to the change in Blaug's thinking and critique of the standard Whig (or, as we will see rational reconstructionist) historiography was the two connected positions he adopted which concerned the growth of knowledge. On the one hand, he turned economists' own market theory tools against them in using an economics of scientific knowledge approach to argue that the 'marketplace of ideas' was neither competitive nor efficient in regard to the production of economic knowledge. From this he was able to argue that the way in which economics developed as a science inevitably involved loss of content, thus undermining the steady progress idea associated with the Whig view, and allowing him to define a role for the history of economic thought in advancing scientific knowledge. On the other hand, he adopted a particular conception of competition, namely, that competition is a process rather than an end state in order to make a case for saying that economic knowledge is path-dependent, by which he meant that economic knowledge at any one point in time depended crucially upon what had previously occurred along the path economists had until then pursued. This then went against the idea that economics amounted to a succession of separable analytic achievements, and justified an essentially evolutionary view of knowledge and science, which accordingly gave historians of economics, with what he saw as their comparative intellectual advantage - a capacity to grasp the depth and breadth of complex interconnections in intellectual history - an important place in advancing the science of economics.

This chapter seeks to explain the genesis and ultimate nature of Blaug's historiographic thinking, first, by reviewing his response to the Whig view held implicitly or openly by most non-historian economists in their attitude toward the history of economics - one which in a number of respects he had at one time shared - and second, by showing how his later evolutionary view of the science of economics led to an altogether different historiographic view which sustained an important role for historians of economics in the development of the field. The second section of the chapter begins by discussing Blaug's response to standard 
historiography in terms of the distinction between rational reconstructions and historical reconstructions of the past. In his first major discussion of the subject - recalling his own recent practice as an historian (Blaug 1985) - Blaug had expressed a fairly strong preference for rational reconstructions, and had also been quite skeptical about whether historical reconstructions were even viable (Blaug 1990). In his second major discussion of historiography, however, he reversed himself, and expressed serious doubts about what rational reconstructions achieve, while also making an argument for historical reconstructions (Blaug 2001). To more fully explain this change in position, the third section lays out Blaug's economics of scientific knowledge argument that the marketplace of ideas is inefficient, implying that the method of rational reconstruction itself is inefficient, and then goes on to explain how he used his process view of competition to take an evolutionary view of the history of economics as path-dependent. The fourth section makes two comments on Blaug's mature view, addressing the role that his 'lost content' assumption plays in evolutionary theory in general, and examining the extent to which his view encounters the problem of reflexivity associated with economics' sociology of scientific knowledge explanations. The fifth section concludes with a discussion of the implications of Blaug's view for the status of the history of economic thought field in the economics profession, particularly with respect to how historians might make the issue of change in economics central to the defense of their field.

\subsection{RATIONAL RECONSTRUCTIONS VERSUS HISTORICAL RECONSTRUCTIONS: A CHANGE OF POSITION}

Blaug drew on the philosopher Richard Rorty (1984) for the distinction between rational reconstructions and historical reconstructions of past ideas (Blaug 1990, 2001). ${ }^{1}$ Both, Blaug emphasized, were inevitably types of reconstructions for the reason that (here he cited the thinking of Jacques Derrida and Michael Foucault), 'all texts of the past need to be reconstructed because they do not speak with one voice and are never unambiguous' (Blaug 2001, p. 151). The relevant question regarding the method of reconstructing the past, he rather argued, was 'how are we to do so: in the light of all that we now know or as faithfully as possible to the times in which they were written' - where the former counted as a 
rational reconstruction and the latter counted as an historical reconstruction (ibid.). Ostensibly the difference was that in the former case the present was one's point of entry, while in the latter case it was the past. Given, then, that each had a certain prima facie plausibility, how was one to decide between the two methods?

In his first discussion of rational and historical reconstruction (1990), Blaug had relied on a distinction between absolutism and relativism - an alternative but related distinction which he had employed in his Economic Theory in Retrospect history of economics (for example, Blaug 1985, pp. 1-2) - to argue that there were important asymmetries between rational and historical reconstructions which tended to favor the former over the latter. First, "we can never forget what we know, so that some version of "absolutism" is implied in every attempt to examine some text of the past', where by absolutism he meant 'the tendency to judge past economic theories by the standards of modern economic theory'. Second, if we take relativism to be the polar opposite of absolutism, then "absolutism" is more defensible than "relativism", particularly as strict "relativism" is logically impossible' (Blaug 1990, p. 28). He then went on to present Paul Samuelson's (1974b) unhesitating defense of rational reconstruction as the clearest possible statement of what that method involved (Blaug 1990, p. 30), and drew up the balance sheet for the two methods in a way that gave mixed but generally favorable support to rational reconstructions, and expressed serious doubts about what historical reconstructions could achieve.

I conclude that rational reconstructions are perfectly legitimate, although whether they are illuminating depends on the case in question. As for historical reconstructions, they are inherently problematic. Strictly speaking they are impossible because they presume that the past can be recalled without knowledge of the present; no adult can be expected to recall his childhood as if adulthood had never happened. (Blaug 1990, p. 30) ${ }^{2}$

Thus at best Blaug was ambivalent, aware from Rorty and others that a case for historical reconstructions might be made, but unclear about how they were to be reasonably done, and thus inclined to defend rational reconstructions as 'legitimate' though perhaps not always 'illuminating'.

Accordingly, when he set out to rethink his views on historiography in economics some ten years later, having experienced how a general acceptance of the method of rational reconstruction in the intervening time had worked against the history of economics, he found himself in a quandary. 'The temptation to choose the first alternative is almost irresistible' (Blaug 2001, p. 151), he still admitted, but one also needed to see that this led to the unacceptable conclusion, as he had previously put 
it, that 'there is really no point to the history of economic thought; why study what Pigou once contemptuously called "the wrong opinions of dead men" (Blaug 1990, p. 28). Defending the method of rational reconstruction, that is, would only confirm the negative verdict of non-historians regarding the history of economic thought that it was simply an idle enterprise outside the bounds of economic science. Was there thus a stronger case, he then asked himself, for understanding the historiography of economics as historical reconstruction, despite its seemingly problematic nature? And was there something objectionable about rational reconstructions that he had previously overlooked? ${ }^{3}$

To uncover his earlier unacknowledged hesitations about rational reconstruction, let us step aside from the abstract epistemological arguments Blaug originally advanced regarding the nature of the two methods, and rather look at how he first saw them applied in practice in connection with the exchange between Samuelson and William Baumol, which had led to Samuelson's characterization of the method of rational reconstruction. There in fact we see a different appreciation of historical reconstructions associated with the emphasis which Blaug sees Baumol putting on the perspective of the historical economist. The starting point in the exchange had been Samuelson's (1971) interpretation and analysis of Karl Marx's famous transformation problem. Samuelson's position was that Marx had simply failed mathematically to simultaneously transform surplus value into profits and labor values into prices. Baumol (1974a) responded to Samuelson that Marx was chiefly interested in the transformation of surplus value into profits (in order to explain the origins of profit in labor exploitation), and that the transformation of labor values into prices had only been of secondary interest to him. So Baumol had argued that mathematical adequacy was not the point in understanding Marx's transformation problem. Samuelson (1974a) nonetheless replied that Marx had still failed at what a comprehensive transformation required, leading Baumol (1974b) to say, yes, but that it had rather been his objective to determine what Marx had intended to do, implying that this was important for understanding Marx and the transformation problem.

Thus as Blaug understood the exchange, the line drawn between the two was over whether economists' intentions and objectives were relevant to understanding their thinking, with Baumol arguing, essentially as an historical reconstructionist, that there were advantages to having this further information apart from how we might view the past from the perspective of contemporary theory. Samuelson thus found himself arguing not only for mathematical adequacy but also that nothing goes missing when we ignore economists' intentions and objectives. One 
could additionally argue on Samuelson's side that one can never know another's intentions, and so they cannot be part of an explanation of economic thinking, ${ }^{4}$ but this argument was really a back-up defense for the position that economists' intentions and objectives were simply irrelevant, whether or not we could say what they were. We can see this in the subsequent exchange of correspondence between Blaug, Samuelson, and Don Patinkin (Samuelson, Patinkin and Blaug 1991) ${ }^{5}$ where the issue became whether a rational reconstruction could deviate from an historical reconstruction. Samuelson's prior position (1974b) had been that all there could be was rational reconstruction, but having read Blaug's account of the exchange with Baumol he found himself on the defensive with regard to whether a rational reconstruction might not be faithful to, or 'deviate' from, an historical reconstruction. As he wrote to Blaug: 'Let's accept for the sake of argument that in some instances a "rational reconstruction" can deviate from a "historical reconstruction", (Samuelson, Patinkin and Blaug 1991, p. 144). Thus he allowed that there seemed to be something to historical reconstructions, even if one preferred rational ones and did not know how to proceed with the other. Rational reconstructions accordingly no longer unequivocally ruled the roost. Blaug seized on this in his response to Samuelson, expanding on Baumol's point that knowing what economists meant to say was important to understanding what they said: 'Is [Hermann Heinrich] Gossen a true forerunner of the Marginal Revolution? No, because no one read him. It is not enough to have great ideas, as Schumpeter always said; you have to get them across to your colleagues' (Samuelson, Patinkin and Blaug, 1991, pp. 148-9). That is, whatever the adequacy, mathematical or otherwise, of Gossen's thinking, we cannot say he was an early marginalist, because marginalism only emerged as a distinct theoretical approach when it was seen explicitly to be such by economists. So knowing what economists think about what they were doing matters to our understanding of what their thinking is.

Thus whereas before Blaug had regarded the method of rational reconstruction as a straightforward, justifiable practice, and had doubts about historical reconstruction, now it was not only clear he thought historical reconstructions had certain advantages over rational ones, and thus must have some sort of coherence, but he had begun to develop doubts about the adequacy of rational reconstructions. Essentially he had reversed his earlier view as a result of his further reflection on Samuelson's statement regarding what the method of rational reconstruction involved in light of the exchange with Baumol. The issue, moreover, concerned what rational reconstructions left out or omitted as explanations which might be recovered through historical reconstructions. This 
focus on omission points us towards the economics of scientific knowledge argument Blaug was to subsequently make regarding the growth of knowledge in economics. ${ }^{6}$

\subsection{LOST CONTENT, THE ECONOMICS OF SCIENTIFIC KNOWLEDGE, AND PATH-DEPENDENCY IN THE HISTORY OF ECONOMICS: AN EVOLUTIONARY VIEW}

Sifting through the various reasons that he found had been given by various authors for studying the history of economic thought (in 'a painfully defensive tone'), Blaug noted that infrequently mentioned was the benefit of discovering 'new' and largely forgotten ideas, a prime example being the rediscovery and rehabilitation of the Pareto optimality concept in the 1930s after more than a quarter century of neglect (Blaug 2001, p. 148). That the profession was blind to this kind of loss of ideas was due, he then argued, to the widely-held view that

the community of economists represents an approximately perfect market in which new ideas are so efficiently transmitted in a communication network of journals, books, seminars and conferences that there is no loss of significant content. This view of an efficient marketplace of ideas implies that history of economic thought can be safely neglected by modern economists, because what is valuable in the ideas is fully contained in the present curriculum. (Ibid.)

But this view of an efficient marketplace of ideas was in Blaug's view as indefensible as it was accepted.

The objections against taking the market of ideas as anything other than a stimulating metaphor are so obvious as hardly to require discussion. In particular, markets as arbiters of quality in scholarly (or any other kind of) goods are excessively subject to bandwagon and snob effects (ibid. pp. 148-9).

The implication of saying that the marketplace of ideas was not perfectly competitive and efficient, then, was that there was there was always a risk of 'loss of content' in current activity as economists followed popular trends. Past ideas that were of continuing value were then regularly discarded, meaning that current ideas were commonly less original and well-founded than generally believed. This was directly contrary to the Whig idea of progress in science and the notion that the advance of economics involved a succession of distinct analytical 
achievements. The method of rational reconstruction, it followed, was itself an inefficient practice, and this suggested that rather some combination of historical and rational reconstruction was needed to generate an efficient scholarly production process.

Blaug thus took it as a given that the growth of knowledge ought to be understood as an economic process, one moreover which could be reasonably well explained with conventional neoclassical concepts such as efficiency and competition. The problem with the profession's abandonment of the history of economics was accordingly that economists had failed to use their analysis to understand their own profession. That is, they did a poor economics of scientific knowledge, and therefore reached the wrong conclusions about the economics production process, the history of economic thought, and the growth of knowledge in economics. This critique was different from ones advanced by many other historians of economics who commonly emphasized the intrinsic value of historical reflection, and were mostly not inclined to use an economics of scientific knowledge approach. However, this is not to say that Blaug as an intellectual historian was unsympathetic to more traditional sorts of arguments about the nature of knowledge and its development:

Knowledge has multi-dimensional depth as well as breadth, and some of the dimensions of economic knowledge include analysis, data, history, institutions and policy questions. There is a raw kind of conceptual depth where concepts are only understood when they are differentiated relative to other closely related ones so that the extent of one's knowledge depends on the fineness with which one can differentiate. In different contexts, these dimensions of knowledge vary in importance. (Ibid. p. 150)

But to deliver a satisfactory critique of standard historiography and the method of rational reconstruction, Blaug needed to employ an argument that operated upon economists' own terrain which they would have to answer but which he believed they could not reasonably rebut. It was one thing, however, to successfully attack rational reconstruction. To go further and advance a positive case for historical reconstruction based on its own merits he needed to go beyond simple marketplace of ideas formulations. This brings us to his argument for a process-conception of competition.

An important emphasis in Blaug's later research in the history of economics concerned how the concept of competition had been understood in the past, and how the modern view of the concept departed from earlier thinking. ${ }^{7}$ The modern view of competition was what he referred to as an end-state conception (Blaug 1997). A good part of the motivation 
behind the adoption of this conception was its tractability for mathematical analysis. But earlier economists had reasoned in terms of a process conception which emphasized the conditions and dynamics of competition.

What Adam Smith meant by competition is what modern Austrians call 'process competition'. What we nowadays call competition was for him 'the obvious and simple system of natural liberty', meaning an absence of artificial constraints and, in particular, restraints on free entry into industries and occupations. Neither competition nor monopoly was a matter of the number of sellers in the market (Blaug 2001, p. 153).

Of course contemporary economists might well argue that what Blaug called a process conception of competition was simply a primitive attempt to understand the formalizable end-state conception, but here Blaug used the process idea to counter this potential response and simultaneously defend the method of historical reconstruction.

Thus, returning to the problem of 'How one can justify the study of the history of economic thought as a specialization within economics', he offered what he regarded as his 'own knock-down argument'.

It is this: No ideas or theory in economics, physics, chemistry, biology, philosophy and even mathematics is ever thoroughly understood except as the end-product of a slice of history, the result of some previous intellectual development. (Ibid., p. 156)

Here what he says is that any end-state or end-product judgment is by itself incomplete as a representation of the economy, and thus inseparable conceptually from the process or development which precedes and produces it. One cannot, then, rationally reconstruct the concept of competition solely in end-state terms, because, despite their desire to formalize, economists know that competitive end states are always the result of processes that generate them. It follows that if we see economics as a marketplace if ideas, as he believed economists should, rational reconstructions, as an end-state type of thinking, must always include historical reconstructions as a process type of thinking, in order to be complete.

From this conclusion, Blaug went on to characterize his view of the growth of knowledge in economics using a key evolutionary concept: path-dependency.

Economic knowledge is path-dependent. What we now know about the economic system is not something we have just discovered, but it is the sum of all discoveries, insights and false starts in the past .... There is nothing predetermined about our current theories and if years ago, economics had 
taken another turn at a critical nodal point, we would today be advocating a different theory. (Ibid.)

Here Blaug's view of path-dependency is subtle. It is not just that there is always a chain of connection between the past and the present that we must trace out in order to have the whole picture. That chain also comprehends many paths not taken, blind alleys, and false starts, which moreover are from time to time revived and re-explored, thus adding cycles of explanation into the history of economics, and undermining the Whig idea of linear progress. ${ }^{8}$ In this way, then, Blaug paints in broad-brush terms the picture of an evolutionary system in which many competing ideas and theories interact with one another, with some prevailing at one point in time and others prevailing at others. Those ideas that lose their temporary advantage may reappear in the future, or even cease to have any significant further role in economics. He consequently goes well beyond the traditional marketplace of ideas metaphor, while still sustaining the idea that competition is a regulating force in a complex evolving world of interdependent theories and ideas.

Blaug contrasted this vision of the history of economics with a more familiar one held by many economists and perhaps some historians of economics as well.

Conversations with other economists have brought home to me that a widely held impression views the history of economic thought as a sort of intellectual archaeology: it may turn up new manuscripts and documents from time to time, but it itself remains unaffected by these discoveries and, unlike other branches of economics, shows no development or progress over time. This is a totally misleading impression. (Ibid., p. 157)

He proceeded to review a number of recent developments in the history of economic thought demonstrating that the status and meaning of many past doctrines was typically up-ended by recent research. This showed that the rational reconstructionist view could not stand since how current theory related to the past was always in jeopardy when the past was in a state of continual transformation. The archaeological view, in effect, was thus an expression of the rational reconstruction view that economics is a succession of separable analytical achievements that proceeded without effects on past economics, but it was increasingly evident that the idea of rational reconstruction itself was incoherent, rather than the reverse as he had originally been tempted to think.

Blaug thus moved his thinking about the historiography of economics a considerable distance from his earlier views. He also made a case for the place of the history of economics in the economics profession that 
was directly contrary to the conventional view. Whereas the history of economics was an incidental, leisure activity in the eyes of most economists, Blaug's argument was that it was absolutely central to the development of economics since one could not say what constituted a scientific advance if one could not appraise new developments in terms of how they related to past ideas and theories. Moreover, to complicate matters, what the history of economics amounted to exhibited change no less than the research frontier of current economics. Yet needless to say, this argument about the history of economics or economics as a whole has not carried the day for many economists. Perhaps this is because it was framed as a defense of the history of economic thought rather than as an explanation of the science of economics per se, but in any event it can be argued that Blaug's evolutionary view of economics may have begun to acquire new relevance in light of the fact that an increasing number of economists are now willing to say that economics research appears to be evolving in a variety of new directions. Thus it is fair to ask, what does Blaug's evolutionary view tell us about the dynamic nature of economics today? In the section that follows I address this question by offering an interpretation of his 'lost content' assumption and by commenting on the problem of reflexivity it raises.

\subsection{THE EVOLUTIONARY VIEW OF ECONOMICS: TWO ISSUES}

Blaug's immediate motivation for saying that economics regularly loses what turns out to be valuable past content (as in the example of the rehabilitation of the Pareto optimality concept) was to show that rational reconstructions are inefficient. Pareto efficient states of affairs, of course, are those in which gains are unequivocal improvements, and nothing valued is sacrificed to produce them. Conversely Pareto inefficient states of affairs are those in which gains come at the expense of losses, and are consequently not unequivocal improvements, in this case where the development of new ideas and theories in economics is at the cost of abandoning earlier ideas and theories that remain valuable.

Thus to argue that economics loses valuable content demonstrates not only that the Whig view of steady progress is mistaken, but that it is so because it fails to satisfy the Pareto standard. Again, Blaug's strategy was to turn economists' own tools against them on the subject of their rational reconstructionist view of the history of economic thought.

But in making this fairly conventional argument he committed himself - it seems at least in part unintentionally - to the view that economics as 
a domain of thinking has a holistic character with evolutionary sorts of dynamics. Consider the following two propositions which are arguably implied by Blaug's position regarding 'lost content'. First, since lost content is usually regarded as being 'correct' in some way when it is first advanced, then 'incorrect' when it is later abandoned, and then once again 'correct' when it gets rehabilitated, the standard for what counts as a 'correct' idea or theory in economics is clearly changeable. Second, since correctness is relative to the views that are dominant at any one time - that any one set of theories and ideas can move back and forth across correctness - implies that there must also be change in what kinds of views are dominant in economics over time. These propositions together, then, suggest that economics operates as a relatively closed discourse which continually recycles relatively durable content, albeit in changing ways. ${ }^{9}$ That is, were it not a relatively closed system in this sense it seems unlikely that past ideas and theories would undergo regular recovery and rehabilitation, on the grounds that substantial changes in the nature and character of economic thinking would disrupt the system of connections that keeps 'incorrect' ideas in play. Perhaps such a view should be termed a 'weak' holism since change in those ideas and theories that are dominant allows more space for bottom-up change in ideas and theories.

That it was not Blaug's explicit intention to reason in these terms might be inferred from his longstanding commitment to the methodology of Imre Lakatos's scientific research program (SRP) approach (for example Blaug 1992). But in his last statement on the subject he advanced a generally holist view of Lakatos's thinking, emphasizing that Lakatos 'denied that it was ever possible to judge an isolated theory; what could be judged and appraised were clusters of more or less interconnected theories, and it was these clusters that he labeled "scientific research programs"' (Blaug 2010, p. 113). Moreover, in regard to Lakatos's treatment of 'progressive' and 'degenerating' changes in research programs, Blaug pointed out that whether a given idea or theory was one or the other depended on its relative performance over time. For example, regarding the various assumptions behind the competitive market 'invisible hand' theorem he argued:

If they are found to be false, this requires a revision of the 'invisible hand' theorem. They may be capable of being accommodated by suitable revision, but only the track record of the research program in the face of possible refutations will establish whether it is a 'progressive' or 'degenerating' SRP ... . The point is that the question of whether an SRP is 'progressive' or 'degenerating' has no 'once-and-for-all' answer. (Ibid., p. 114) 
Thus it seems fair to say that there were evolutionary holist ideas in Blaug's thinking about the ways in which economics developed and changed over time, despite the fact that he did not emphasize them explicitly or apparently see himself as an evolutionary thinker per se.

This then raises the question of how he saw his own role in regard to the arguments he made about the historiography of economics. Were those arguments, particularly as economics of scientific knowledge arguments regarding the inefficiency of rational reconstructions of the past, to be judged as merely relative to 'clusters of more or less interconnected theories' about the historiography of economics, and so perhaps to be seen as 'correct' at one time but then abandoned and 'incorrect' at another, perhaps to be rehabilitated and recovered again later? This is the issue of reflexivity, or how one's arguments regarding methodological practice apply no less to one's own arguments than to those to whom they are directed. It is an issue particularly appropriate to Blaug's thinking because he casts his critique of rational reconstruction in economic terms via the marketplace of ideas metaphor, and then uses the 'lost content' idea to show that ideas and theories are ultimately relative to changes in dominant thinking in economics. This then invites those who would like to resist his critique of rational reconstruction to argue that he has not advanced any definitive argument for historical reconstruction. Indeed, if there is a general recycling of ideas and theories in economics as might follow on his view, then one might say that Whig type views of economics historiography should have their day as frequently as Blaug's preferred view of the history of economics.

One way to address this problem and escape the often paradoxical aspects of the concept of reflexivity is by distinguishing different levels in the application of the concept (Davis and Klaes, 2003). A first level of reflexivity involves what may be called an 'immanent' reflexivity, where ideas and theories not only refer to objects in the world but are also self-referring. This is the case with the economics of scientific knowledge as a particular approach in economic methodology, since economics is being evaluated in terms of the concepts of economics. A second level of reflexivity involves what may be called an 'epistemic' reflexivity, where there is a relationship between a methodologist or epistemologist, Blaug in this case, and the economics of scientific knowledge (itself 'immanently' reflexive) such that his own arguments refer not only to the thinking of other economists but are also self-referring, as argued in the previous paragraph. A third level of reflexivity involves what may be called a 'transcendent' reflexivity, where we ourselves, economists generally, and all those interested in the arguments concerning the role and nature of the history of economic thought look upon Blaug's 
historiographic view (the 'epistemic' level of reflexivity) and do so in a self-referring way, or in a way that refers back upon us, since we are concerned with the same historiographic issues.

Reflexivity exists at all three levels, then, but its paradoxical quality dissipates as one moves from lower to higher levels. Thus it may seem highly paradoxical in light of the evident circularity to say, at the 'immanent' level, that the meaning of ideas and theories in economics derives from the meaning of those same ideas and theories. But this difficulty is at least moderated when the methodologist or epistemologist; who stands outside those ideas and theories, discusses at the 'epistemic' level whether, when, and how successfully economic ideas and theories can be used to evaluate the development of the field of economics objectified as a type of scientific practice. Nonetheless there still remains something problematic about 'epistemic' reflexivity where, as we saw with Blaug, it is fair game to say that a particular methodology that is grounded in certain ideas and theories ought to be judged by itself, another evident circularity.

Consider, then, how we might look upon Blaug's position in 'transcendent' reflexivity terms. Here we focus not on the ('epistemic') relationship between the particular methodologist Blaug and the views he developed but rather on collections of individuals like Blaug, Samuelson, Baumol, others, and ourselves, who are involved in seeking to explain a type of disciplinary practice, namely the history of economic thought, as it operates in the science of economics understood as one among many kinds of social sciences. Here we place Blaug in this wider social context in which at issue is not just his arguments regarding the status of the history of economics but generally how the social science disciplines function and ought to function. Blaug is still an historian and methodologist of economics, and he still thinks in terms of a relatively closed discourse in which he is expert. But our vantage point is now broader, and the representative case he makes against the view most economists defend regarding the historiography of economics is framed by how sciences generally operate on such subjects as 'lost content' and change.

Thus, in light of the fact that Blaug uses economics of scientific knowledge reasoning to evaluate economics on historiography, the reflexive aspects of his thinking need to be recognized and addressed. But ultimately his case for the method of historical reconstruction is more widely based and not really vulnerable to the circularity critique. In the closing section, then, lessons from his case and arguments for the history of economic thought are set out in relation to the issue of change in recent economics. 


\subsection{HISTORY OF ECONOMICS AND THE CHANGE IN ECONOMICS}

As already noted, it is now widely recognized in the economics profession that there has been considerable change in ideas, theories, methods, and approaches in economics in the last decade or more. Perhaps not surprisingly, this has given new impetus to appraisals of past ideas as proponents of new research strategies interpret them in terms of past ideas and theories (for example Bruni and Sugden 2007). In one sense, this is consistent with Blaug's view that the past can be recovered and rehabilitated. It also fits his critique of the archaeological view of the history of economic thought, where he argues that the past is not set in stone and there simply to be uncovered, but is continually being explained anew as continued research leads us to revise our past historical thinking. But to the extent that these recent 'recoveries' are rational reconstructions of the past, perhaps with Whig-type motivations, they would be as objectionable to Blaug as views such as Samuelson's ultimately became for him. Nonetheless, might it be argued, with Blaug's implicit evolutionary vision of economics in mind, that there are grounds for thinking that economists, especially those who are involved in new research approaches and who often find themselves at odds with dominant views, are potentially more open to thinking that 'correctness' in economics is relative, and consequently that the history of economics could be valuable to understanding the development of economics as a science? Certainly there are reasons not to be too optimistic on this score, but it seems fitting in a discussion of Blaug's contributions to the historiography of economics to at least make the case for a more optimistic scenario.

The argument, then, would be that the Samuelsonian idea that past ideas and theories can and ought to be rationally reconstructed is no longer nearly as credible as it was many years ago, that it has become increasingly accepted that historical reconstruction is the proper form of historiography, and, most importantly, that this all shows that economics can lose content seen to be of continuing value. Why should we think these three claims are true? First, rational reconstruction is now arguably seen as a naïve method, one not seriously defended any longer by economists, most of whom seem to have originally only followed the lead of Samuelson, while being less competent than he was in arguing it, and so are today not so much averse to the history of economics per se as just interested in increasing training in mathematics and econometrics. At the same time, whereas a leading historian of economics, Blaug, could 
entertain rational reconstruction at one point in his career, there are far fewer historians of economics now who would take that view seriously. Second, economists, even when they have no interest in the history of economics, generally accept that historians of economics are expert in their field, and recognize that the field has expanded in a research sense with more publications and journals than previously. Thus if historians with expert status defend historical reconstruction, likely economists generally will take that to be the proper method. Third, the main feature of the change in recent economics is a multiplication in research approaches exhibiting considerable incommensurability with one another. Supposing that economists increasingly recognize this, they should then be aware that there are significant gaps in research, as is often manifest in researchers' successes in seizing upon unexploited subjects of investigation, and thus be more open to the idea that valuable economic ideas and theories may sometimes be missed, neglected, and sometimes also recovered. In effect, then, Blaug's inefficiency of the economics marketplace idea is no longer really a very controversial idea among economists.

This optimistic scenario, whereby the view of history of economic thought in the economics profession has changed from what it was previously, unfortunately does not imply that resources will flow to the field or that it will make significant progress in the future in being re-established in doctoral study. As worldwide there are fewer resources directed to university training in general, fields such as the history of economics which are not at the center of their subjects will continue to face difficult times. But it may be taken nevertheless as a legacy of Mark Blaug's work as an economist, historian, and methodologist of economics to have made a strong case for the field. And who would have been a better person to have done so than one who admitted he had been wrong about rational reconstruction because it failed by economists' own measure of policy, Pareto efficiency?

\section{NOTES}

* Thanks for comments without implication on a previous version of this chapter go to Marcel Boumans, Tony Brewer, Bruce Caldwell, Zohreh Emami, Wade Hands, Matthias Klaes, Harro Maas, Jack Vromen and Altug Yalcintas.

1. Rorty, whose concern was the history of philosophy, distinguished four genres of historiography: Geistesgeschichten, historical reconstructions, rational reconstructions, and doxographies (Rorty 1984). Blaug thought that "intellectual history" or "geistesgeschichte" ... virtually the same thing as what I call "historical reconstruction"" (Blaug 2001, p. 151), and the difference between doxography and rational constructions 'at best a subtle one' (Blaug 1990, p. 28). His main distinction across his two 
papers, consequently, was the difference between rational reconstructions and historical reconstructions.

2. A somewhat more blunt assessment of his view at this time was recorded later in his 1994 autobiographical remarks with respect to his historiographical stance in Economic Theory in Retrospect: 'I announced myself an unapologetic absolutist and poked fun at relativists throughout the book. This is not a point of view I now hold, having been upstaged over the years by even more strident upholders of the "Whig interpretation of history"' (Blaug 1994, p. 17).

3. It is worth noting that Blaug was also motivated to reconsider the merits of rational reconstruction by his perception of the unhealthy emergence of formalism in economics (cf. Blaug 2003).

4. This was important to George Stigler's position (cited by Blaug) in contrasting 'personal exegesis' and 'scientific exegesis' (Stigler 1965).

5. This subsequent exchange was stimulated by Samuelson's reaction to Blaug's (1990) reflections on historiography and discussion of the exchange with Baumol. Samuelson widened the exchange to include Patinkin, and their correspondence largely concerned other issues in the history of economics.

6. Note that Imre Lakatos, who much influenced Blaug on the subject of the methodology of scientific research programs, had much earlier made related statements, arguing that 'any rational reconstruction needs to be supplemented by an empirical (sociopsychological) "external history" (Lakatos 1971, p. 91). Thus he wrote:

In this paper I have proposed a 'historical' method for the evaluation of rival methodologies. The arguments were primarily addressed to the philosophers of science and aimed at showing how he can - and should - learn from the history of science. But the same arguments also imply that the historian of science must, in turn, pay serious attention to the philosophy of science and decide upon which methodology he will base his internal history. I hope to have offered some strong arguments for the following theses. First, each methodology of science determines a characteristic (and sharp) demarcation between (primary) internal history and (secondary) external history and, secondly, both historians and philosophers of science must make the best of the critical interplay between internal and external factors. (Ibid., p. 122)

Blaug, however, does not seem to have cited this text. See Klaes (2003) for a discussion of Lakatos's view.

7. This was central to his critique of formalist general equilibrium theory (for example Blaug 2003).

8. Thus on the one hand: "At long last, it can be said that the history of general equilibrium theory from Walras to Arrow-Debreu has been a journey down a blind alley', whereas on the other hand: 'General equilibrium theory, which had been dying a slow death ever since Walras's own death, was revived in the 1930s' (Blaug 2001, p. 160).

9. This argument was also advanced in a somewhat different manner by Daniel Hausman (1992).

\section{REFERENCES}

Baumol, W. (1974a), "The transformation of values: What Marx "really" meant (an interpretation)', Journal of Economic Literature, 12 (1), 51-62.

Baumol, W. (1974b), 'Comment', Journal of Economic Literature, 12 (1), 74-75. 
Blaug, M. (1985), Economic Theory in Retrospect, 4th edition, Cambridge: Cambridge University Press.

Blaug, M. (1990), 'On the historiography of economics', Journal of the History of Economic Thought, 12 (1), 27-37.

Blaug, M. (1992), The Methodology of Economics, or How Economists Explain, 2nd edition, Cambridge: Cambridge University Press.

Blaug, M. (1994), 'Not only an economist - autobiographical reflections of a historian of economic thought', The American Economist, 38 (2), 12-27.

Blaug, M. (1997), 'Competition as an end-state and competition as a process', in B.C. Eaton and R.G. Harris (eds), Trade, Technology and Economics: Essays in Honour of Richard G. Lipsey, Cheltenham, UK and Lyme, NH, USA: Edward Elgar, pp. 241-263.

Blaug, M. (2001), 'No history of ideas, please, we're economists', Journal of Economic Perspectives, 15 (1), 145-164.

Blaug, M. (2003), 'The formalist revolution of the 1950s', Journal of the History of Economic Thought, 25 (2), 145-156.

Blaug, M. (2010), 'Research programs in economics', in M. Boumans and J.B. Davis, Economic Methodology: Understanding Economics as a Science, Basingstoke: Palgrave Macmillan, pp. 113-114.

Bruni, L. and R. Sugden (2007), 'The road not taken: How psychology was removed from economics, and how it might be brought back', Economic Journal, 117 (January), 146-173.

Davis, J. and M. Klaes (2003), 'Reflexivity: curse or cure?', Journal of Economic Methodology, 10 (3), 329-352.

Hausman, D. (1992), The Inexact and Separate Science of Economics, Cambridge: Cambridge University Press.

Klaes, M. (2003), 'Historiography', in W.J. Samuels, J.E. Biddle and J.B. Davis (eds), A Companion to the History of Economic Thought, Oxford: Blackwell, pp. 491-506.

Lakatos, I. (1971), 'History of science and its rational reconstructions', in R.C. Buck and R.S. Cohen (eds), Boston Studies in the Philosophy of Science 8, Dordrecht: Reidel, pp. 91-136.

Rorty, R. (1984), 'The historiography of philosophy', in R. Rorty, J.B. Schnewind and Q. Skinner (eds), Philosophy in History, Cambridge: Cambridge University Press.

Samuelson, P. (1971), "Understanding the Marxian notion of exploitation: A summary of the so-called transformation problem between Marxian values and competitive prices', Journal of Economic Literature, 9 (2), 399-431.

Samuelson, P. (1974a), 'Insight and detour in the theory of exploitation', Journal of Economic Literature, 12 (1), 62-70.

Samuelson, P. (1974b), 'Rejoinder: Merlin unclothed, a final word', Journal of Economic Literature, 12 (1), 75-77.

Samuelson, P., D. Patinkin and M. Blaug (1991), 'On the historiography of economics: A correspondence', Journal of the History of Economics, 13 (2), $144-158$.

Stigler, G. (1965), 'Textual exegesis as a scientific problem', Economica, 32 (November), 447-450. 